\title{
From the Legacy of 19th-Century Ukrainian Intellectuals: Two Seminal Essays
}

\author{
Marko Robert Stech
}

Canadian Institute of Ukrainian Studies, Toronto Office, University of Alberta

\begin{abstract}
A mong several ambitious projects initiated in the early 1970s by Professor Omeljan Pritsak at the Ukrainian Research Institute at Harvard University (HURI), was a program of preparing English translations of key works of the Ukrainian intellectual tradition, including short essay-length texts. For various reasons, a considerable number of these essays, translated at that time, remained unpublished. Preserved in manuscript form by such former HURI scholars as Paul R. Magocsi and Frank E. Sysyn, these texts have been progressively made accessible to readers only in recent years within the contexts of various publication projects at the Canadian Institute of Ukrainian Studies (CIUS). In 2013, a selection of seminal texts by three prominent scholars and leaders of the Ukrainian national movement of the nineteenth century-Mykola Kostomarov, Volodymyr Antonovych, and Mykhailo Drahomanov-were published by the CIUS Press in the book: Fashioning Modern Ukraine: Selected Writings of Mykola Kostomarov, Volodymyr Antonovych, and Mykhailo Drahomanov. Edited by Serhiy Bilenky, this book appeared within the Manuscript Series of the Peter Jacyk Centre for Ukrainian Historical Research at the CIUS. The majority of texts included in that edition had been translated decades ago as part of the above-mentioned HURI translation project.

With the publication of Nik[olai] Fabrikant's [Ivan Krevets'kyi's] article "A Brief Outline of the History of the Treatment of Ukrainian Literature by the Russian Censorship Laws" in vol. 4, no. 2 (2017), the East/West: Journal of Ukrainian Studies began to make available to its readers some other essays from Pritsak's HURI translation project. In this issue, readers will find translations of two important texts related to two major scholars of Ukrainian origin who played prominent roles in the scholarship and intellectual milieu of the nineteenth-century Russian Empire. Both texts have hitherto been unavailable in English.

The first text is the essay "Language and Nationality" by, arguably, the most prominent linguist and philosopher of language in the Russian Empire of the second half of the nineteenth century, Oleksandr Potebnia (born in Poltava in 1835, died in Kharkiv in 1891). Unpublished during the author's
\end{abstract}


lifetime, this essay was found by Potebnia's students among his papers after his death; it was edited by some of these students (quite probably, Vasyl' Khartsiiev) and was published for the first time in 1895. Though unauthorized by Potebnia and rather fragmentary and incomplete in its concluding section, this essay, nevertheless, had a considerable influence on later scholars and, in particular, on twentieth-century Ukrainian linguists and educators. After all, this text addresses one of the serious issues that Ukrainians had to face during the nineteenth century and much of the twentieth century, during the times when they lived under oppressive foreign dominations and were subjected to intense denationalization through Russification, Polonization, Germanization, Magyarization, Romanization, and other assimilatory pressures. Potebnia's views, expressed in his essay, on the crucial importance of well-functioning native languages and educational systems in these native languages for the proper and harmonious development of peoples and nations, resonated with those Ukrainian intellectuals who felt that, under the adverse conditions in which they lived, the very existence of the Ukrainian language, identity, and distinctive national life was under grave threat. Thus, for example, in the 1930s, prominent linguist Vasyl' Simovych based his publication Ridna mova $i$ intelektual'nyi rozvytok dytyny (Native Language and the Intellectual Development of a Child) on the ideas expressed in Potebnia's "Language and Nationality," which he then expanded into a more complete theory.

Most likely, one of the primary reasons the essay "Language and Nationality" was not published, or even properly completed and prepared for publication by Potebnia himself, was its subject matter and the fact that Potebnia's views were in stark contrast with the Russian policies vis-à-vis the Ukrainian language and with the official scholarly discourse sanctioned by the tsarist censorship. One of the inspirers of the Sunday school movement and an ardent proponent of the Ukrainian-language education system for the Ukrainian gubernias in the Russian Empire in the 1850s and early 1860s, Potebnia could no longer openly express such views after 1863-the year when Petr Valuev's secret directive sharply curbed the use of the Ukrainian language in education, publications, and public life; this was also the year that Potebnia himself was harassed by the tsarist police, vilified in conservative Russian press, and reprimanded by his Kharkiv University superiors for his alleged "Little Russian separatism" (Sheveliov 26; see also Moser). The situation became even worse after 1876 when Tsar Alexander II issued the infamous Ems Ukaz that banned all Ukrainian-language publications, the staging of plays, performances, and public readings in Ukrainian, the printing of Ukrainian lyrics to musical works, etc. The Ukaz effectively paralyzed Ukrainian cultural and intellectual life in the Russian Empire and, in addition, made the censorship even of Russian-language publications devoted to Ukrainian topics still harsher than earlier. Although 
in his essay Potebnia carefully avoided any direct references to the Russian government's suppression of the Ukrainian language, the crux of his ideas and the logic of his argumentation, when applied to the Ukrainian situation, were, in their very core, fundamentally opposed to the tsarist anti-Ukrainian policies. Thus, very likely, the censorship would not have permitted the publication of this essay in the form that would give justice to the ideas that Potebnia wanted to express.

Potebnia's only attempt to discuss the topic of the interrelationship between language and nationality in an officially printed publication was a short section in his extensive review of Iakiv Holovats'kyi's collection of Galician and Transcarpathian folk songs. Potebnia's very interesting polemical remarks, in which he concisely outlined his main ideas on the subject, were inserted in-between two lengthy sections containing highly complex linguistic analyses of the folk material provided by Holovats'kyi. Almost certainly, the objective of such a manoeuvre was to "sneak" this polemical text past the tsarist censors, since it would have been very likely that any censor would have long abandoned reading the complex scholarly narrative before getting to this "subversive" section. In this text Potebnia quite openly and emotionally expressed his criticism (to the point of outrage) of the denationalization tendencies reported among some Ukrainians who lived in western Ukraine under Austrian rule, thus very clearly hinting at (although never stating explicitly) his views and attitudes toward much more serious and widespread denationalization processes among Ukrainians in the Russian Empire. But, evidently, the scholar gave up the idea of trying to publish a longer separate essay devoted to this "controversial" problem in some official imperial scholarly journal.

Thus, regrettably, the text of "Language and Nationality" in the form in which it had been preserved presents a contemporary reader with certain questions and challenges. Apart from being somewhat fragmentary and disjointed (especially in its final section), the essay lacks any clear and straightforward concluding remarks. Thus, some later scholars, including George Shevelov, raised a question of whether Potebnia might have abandoned his work on this essay not only because of pragmatic concerns (i.e., the problem of censorship), but because he might have, late in his scholarly career, changed some of the views that had formed the fundamental basis of his "Language and Nationality" (Sheveliov 39).

Moreover, we must keep in mind that in spite of the fact that Potebnia ended up not trying to publish this text, he, nevertheless, wrote it in a way that generally conformed to the restrictions and limitations imposed by tsarist censorship; that is, this essay was quite clearly "self-censored" by the author. One example of that is his rather confusing usage (as in most of his post-1863 publications) of the officially sanctioned term for the Ukrainian language. Although in his private correspondence (especially with people 
whom he knew and trusted), Potebnia used the term "the Little Russian language" ("malorusskii iazyk") (Sheveliov 15), in many of his scholarly publications he was compelled to refer to it as the "Little Russian dialect" ("malorusskoe narechie") or "Little Russian dialects" ("malorusskie narechiia"). However, in contrast to the majority of other scholars in the Russian Empire of his time, Potebnia concurrently referred to the language spoken by the Russians of his day as the "Great Russian dialect" ("velikorusskoe narechie") or (as in this essay) "Great Russian dialects" ("velikorusskie narechiia"). This stemmed from quite a peculiar understanding of the term "the Russian language" ("russkii iazyk") in Potebnia's texts. As explained by Shevelov, "the Russian language" "in Potebnia's terminology refers to the East Slavic [language]" (31), that is, the language that had been the source not only for Ukrainian, but also for modern Russian and Belarusian. Thus, in his particular use of terminology, distorted by the dictates of tsarist censorship, the upstanding scholar Potebnia managed, in the end, to treat the Ukrainian and Russian languages of his time as equal and equally important. In any case, a reader of this English translation of "Language and Nationality" should keep in mind Potebnia's unorthodox use of terminology.

In spite of the above-mentioned somewhat problematic issues, "Language and Nationality" is an important essay that showcases very well Potebnia's general views on the impact of language and national identity on the psychology and social development of individuals. Very skeptical about the "universalist" views on language expressed by scholars who envisaged an eventual usage of one universal language by all of humanity, Potebnia was an ardent critic of denationalization and a strong proponent of unimpaired development of all languages and dialects, which he equated with unique and unrepeatable systems of thought, feeling, and worldview. Thus, on account of that and on account of its significant impact on the subsequent development of Ukrainian scholarship and intellectual thought, it is important to present this essay in English to international readers.

The subject matter of the second essay presented in this issue is the philosophical thought of another major Ukrainian intellectual of the nineteenth century, Pamfil Iurkevych (born in the village of Lipliave, Poltava gubernia, in 1826, died in Moscow in 1874). The most prominent philosopher in the Russian Empire of his time, Iurkevych wrote almost all of his philosophical works in Kyiv where he was a professor at Kyiv Theological Academy and where he gained wide recognition as an erudite scholar and brilliant lecturer. (A fictionalized portrait of the philosopher, revered by the Academy students, was preserved for us by Ivan Nechui-Levyts'kyi in his novel Khmary [Clouds] in the character of Vasyl' Dashkovych.) Iurkevych was considered the only scholar in the Russian Empire qualified to assume the Chair of Philosophy at Moscow University, after the tsarist ban on teaching 
philosophy at Russian universities was lifted in 1861. However, in Moscow, Iurkevych's idealist philosophical outlook was harshly criticized on ideological grounds by so-called "progressive" Russian intellectuals such as Nikolai Chernyshevskii. Iurkevych's opponents could not match the scholar's brilliant erudition, so their "polemic" soon took the form of defamation of character and virulent personal slander. Pointing out that "the entire progressive Russian press, during that period of the total nonexistence of philosophical culture [in Russia] [...], jointly assaulted Iurkevych as a political enemy," Dmytro Chyzhevs'kyi described the conflict as follows:

One can hardly call this polemic, instigated by Chernyshevskii, by any other name than a crusade [launched by the forces] of ignorance and philistinism, who, being unable to stand up to the power of thought with [their own] thought, substituted [rational] polemic with insults, lies, and personal attacks. Iurkevych had no means to defend himself against such methods and he fell silent [and remained silent] for many long years. (138)

Although intellectually primitive and factually unsubstantiated, these attacks took a heavy toll on Iurkevych; most likely, they contributed to his grave illness and early death. Also, the adverse conditions of his life and work in Moscow resulted in very few scholarly texts being published in the last decade of his life.

The essay presented in the English translation in this issue was written by Iurkevych's most famous student, Vladimir Solov'ev, one of the most important figures of the so-called "Silver Age" of Russian literature. Incidentally, Moscow-born Solov'ev was closely tied to Ukraine in general, and the Ukrainian philosophy in particular. His mother hailed from a Ukrainian noble family and Solov'ev greatly prided himself on the fact that, on his mother's side, he was a blood relative of the famed Ukrainian philosopher Hryhorii Skovoroda. As for his opinion of Iurkevych, Solov'ev did, throughout his life, acknowledge his teacher's vital influence on his intellectual development.

Written in 1874, very soon after Iurkevych's death, Solov'ev's essay “On the Philosophical Works of P. D. Iurkevych" was the first serious attempt to analyze and summarize the essence of Iurkevych's philosophical teachings. In fact, this text retained its significance as one of the most thoughtful analyses of Iurkevych's oeuvre up until the end of the twentieth century and the disintegration of the USSR, in which Iurkevych's legacy had at times been banned, and at other times fully ignored. And, although some valuable publications on Iurkevych and his philosophy (notably, a Ukrainianlanguage edition of his Selected Works in 1993) appeared in independent Ukraine, Solov'ev's essay even today can serve as an excellent concise introduction to the complex philosophical thought of this greatly understudied nineteenth-century Ukrainian philosopher, who, during his 
day, made a weighty contribution to the development of philosophical thought in the Russian Empire. As such, this text deserves to be made available in English to the international scholarly community.

\section{Works Cited}

Bilenky, Serhiy, editor. Fashioning Modern Ukraine: Selected Writings of Mykola Kostomarov, Volodymyr Antonovych, and Mykhailo Drahomanov. CIUS P., 2013.

Chyzhevs'kyi, Dmytro. Narysy $z$ istorii filosofii na Ukraini. Prague, Ukrains'kyi hromads'kyi vydavnychyi fond, 1931.

Fabrikant, Nik. (Ivan Krevets'kyi). "A Brief Outline of the History of the Treatment of Ukrainian Literature by the Russian Censorship Laws." East/West: Journal of Ukrainian Studies, vol. 4, no. 2, 2017, pp. 153-72. http://ewjus.com/index.php/ewjus/article/view/327. Accessed 8 Sept. 2019.

Iurkevych, Pamfil. Vybrane. Abrys, 1993.

Moser, Michael, guest editor. Banning a Language "That Does Not Exist": The Valuev Directive of 1863 and the History of the Ukrainian Language. Special thematic section of East/West: Journal of Ukrainian Studies, vol. 4, no. 2, 2017, pp. 3-172.

Potebnia, Aleksandr. (Oleksandr Potebnia). "Narodnyie pesni Galitskoi i Ugorskoi Rusi, sobranyie Ia. F. Golovatskim. Retsenziia." Zapiski Imperatorskoi Akademii Nauk (St. Petersburg), vol. 37, bk. 2, app. 4, 1881, pp. 64-152.

Sheveliov, Iurii. (George Shevelov). “Oleksander Potebnia i ukrains'ke pytannia: Sproba rekonstruktsii tsilisnoho obrazu naukovtsia." In Oleksander Potebnia, Mova. Natsionalizm, Denatsionalizatsiia: Statti i fragmenty. Ukrainian Academy of Arts and Sciences in the U.S., Inc., 1992, pp. 7-46.

Simovych, Vasyl'. Ridna mova i intelektual'nyi rozvytok dytyny. Lviv, 1934. 